\title{
Consumer Behaviour Towards Best Bus in Mumbai City Post Lockdown
}

\author{
Rahul N. Wadekar ${ }^{1}$, K.Y. Shinde ${ }^{2}$ and Kanwalpreet Kaur Puri ${ }^{3}$ \\ ${ }^{1} M M S$ Department, DES's NMITD, University of Mumbai, India \\ ${ }^{2}$ Bharat Education Society's Sant Gadge Maharaj College of Commerce and Economics, \\ Khetwadi, Girgaon, Mumbai, India \\ ${ }^{3}$ Dhirajlal Talakchand Sankalchand Shah College of Commerce (DTSS), Malad (E), Mumbai, India
}

\section{ABSTRACT}

Corona Virus, pandemic created turmoil in the entire world. The purpose of the study is to analyse the change in preference of Mumbaikar's towards BEST BUS post lockdown for commuting to various destinations. The Wilcoxon signed rank test was applied to evaluate change in the preference in pre and post lockdown towards the BEST bus. There was a significant change in preference for the bus in post lockdown towards going to the workplace, attending funerals, visiting hospitals, educational purposes and sightseeing. The study definitely fulfil the objectives and further studies can be conducted to find out the various factors that contribute to the change in preference of commuters post lockdown.

\section{KEY WORDS: BEST BUS, COMMUTING, CONSUMER BEHAVIOUR, LOCKDOWN, PUBLIC TRANSPORT.}

\section{INTRODUCTION}

Humans respond differently to different circumstances. Corona Virus, an unwelcome crisis, declared as a pandemic in March 2020, created an environment of anxiety and panic for all. To arrest the spread of the infection, a complete lockdown was imposed in major parts of the world. This led to a decline in the normal activities and thereby an extreme impact on the economies of the nation. The sudden closure had an effect on the entire world, and a remarkable change was observed in the consumer's behaviour since the virus hit the entire economy.

Biosc Biotech Res Comm P-ISSN: 0974-6455 E-ISSN: 2321-4007

\section{crossef}

Identifiers and Pagination

Year: 2021 Vol: 14 No (5) Special Issue

Pages: 27-31

This is an open access article under Creative

Commons License Attribn 4.0 Intl (CC-BY).

DOI: $h t t p: / / d x . d o i . o r g / 10.21786 / b b r c / 14.5 / 5$
The uncertainty in the mind of individuals was obvious and a change in the behaviour was expected. There was a mixed reaction amongst the people across the globe. An increase in the purchase of the essential commodities and services was seen, whereas demand for certain goods and services was postponed. The fear of this pandemic changed the priorities and lifestyle of the majority. The situation in the Mumbai city was no different. There was a spike in the number of cases. The standard operating procedure was issued by the Ministry of Home Affairs for the functioning of the state and the cities. The government tried its best to follow the preventive guidelines so as to minimise the spread of the virus.

The lockdown forced the people to work remotely. The majority of the work shifted to the virtual mode and people embraced technology like never before. This turned out to be the chief reason for the decline of the transport sector. Transport is the category which is likely to lose because of the pandemic. The state government of Mumbai allowed only the movement of essential workers in the initial days, and the services of local trains and BEST buses were operational only for them. After the partial unlock, a few people started commuting to their work places and for regular needs, but a change

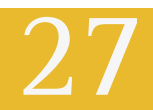


in behaviour towards various travel modes was seen. Individuals started choosing a mode which they believed as safe.

Health, hygiene and safety became the priority of the people. Although the buses were in demand, but an increase in own vehicles was also reported. This generated the interest of the researcher to look into consumers (commuters) preference towards Brihanmumbai Electricity Supply and Transport (BEST) bus services for commuting to various destinations post lockdown in the city of Mumbai, which was the only available public mode for commuting during and post lockdown.

Literature Review: Gutierrez, Aaron et al (2020) points out the prominent challenges for public transport during the times of COVID 19. The world came to a standstill with the lockdown imposed. Once the initial restrictions were lifted, people started travelling again, but the preference for public transport declined. The major reason for avoiding this mode was the fear of contracting the infection. The fear was obvious, and was bound to impact the psychology of the customer.

Even though the services followed all the safety guidelines, still managing the public with social distancing and masks was a task. The less occupancy ratio led to reduced income of the public sector. This sudden change made individuals opt for private modes. The lower income group was the most affected as they had only this mode as an option. The study mentions that the degrading environment will further deteriorate because of this pandemic, and now the society should move towards more sustainable modes of transportation.

The already stressed public mode has now another reason to worry. Keeping in mind the previous pandemics and this virus, the planning for transport needs reforms. If travel behaviour changes of the majority, it will lead to a great environmental loss in future and create further imbalances in the society as not everyone can afford private modes.

Shen, Jin et al (2020) brings to notice the actions implemented for the public transport in China during the outbreak of Corono Virus. The fear of the spread of infection is more in a closed environment and in crowded places. The strategies adopted by the country limited the spread of the virus. The study suggested providing training to the staff members so that they can handle themselves as well as the passengers well; adequate use of sanitizers, masks and disinfectants; avoiding crowding in the vehicle by monitoring the passenger flow; regular cleaning of the surfaces and the premises; maintaining social distance and educating passengers about the safety measures to be followed. Public transport is one of the most needed modes of transport and strengthening the safety strategies will reduce the spread of the infection. The entire world will have to be extra cautious when the activities resume full-fledged. The challenges for developing countries will be more as they have a huge population using public modes, and preventive strategies require a good number of financial resources as well.

Sheth, Jagdish (2020) ponders about the change in the consumer's behaviour because of the COVID -19 pandemic. The paper summarises eight major effects of this pandemic on the consumption, namely hoarding of essentials, improvising and adjusting with the available resources, postponing demand of non- essentials, accepting the digital world, online shopping, adapting to the new work-life balance, reaching to the world through video calls and utilising the available time to discover one's talents.

\begin{tabular}{|c|c|c|c|c|c|}
\hline & & Frequency & Percent & Valid Percent & Cumulative Percent \\
\hline \multirow[t]{3}{*}{ Valid } & \multirow{3}{*}{$\begin{array}{c}\text { Female } \\
\text { Male } \\
\text { Total }\end{array}$} & 34 & 55.7 & 55.7 & 55.7 \\
\hline & & 27 & 44.3 & 44.3 & \multirow[t]{2}{*}{100.0} \\
\hline & & 61 & 100.0 & 100.0 & \\
\hline
\end{tabular}

Table 2. Occupation

\begin{tabular}{|c|c|c|c|c|c|}
\hline & & Frequency & Percent & Valid Percent & Cumulative Percent \\
\hline \multirow[t]{5}{*}{ Valid } & \multirow{5}{*}{$\begin{array}{c}\text { Business } \\
\text { Not working } \\
\text { Salaried } \\
\text { Student } \\
\text { Total }\end{array}$} & 3 & 4.9 & 4.9 & 4.9 \\
\hline & & 4 & 6.6 & 6.6 & 11.5 \\
\hline & & 25 & 41.0 & 41.0 & 52.5 \\
\hline & & 29 & 47.5 & 47.5 & 100.0 \\
\hline & & 61 & 100.0 & 100.0 & \\
\hline
\end{tabular}




\begin{tabular}{|c|c|c|c|c|}
\hline & & $\mathrm{N}$ & Mean Rank & Sum of Ranks \\
\hline \multirow[t]{4}{*}{ Post workplace - pre workplace } & Negative Ranks & $11 \mathrm{a}$ & 16.05 & 176.50 \\
\hline & Positive Ranks & $38 b$ & 27.59 & 1048.50 \\
\hline & Ties & $12 c$ & & \\
\hline & Total & 61 & & \\
\hline \multirow[t]{4}{*}{ Post native - pre native } & Negative Ranks & $17 d$ & 13.44 & 228.50 \\
\hline & Positive Ranks & $16 \mathrm{e}$ & 20.78 & 332.50 \\
\hline & Ties & $28 \mathrm{f}$ & & \\
\hline & Total & 61 & & \\
\hline \multirow[t]{4}{*}{ Post education - pre education } & Negative Ranks & $47 \mathrm{~g}$ & 28.17 & 1324.00 \\
\hline & Positive Ranks & $5 \mathrm{~h}$ & 10.80 & 54.00 \\
\hline & Ties & $9 \mathrm{i}$ & & \\
\hline & Total & 61 & & \\
\hline \multirow[t]{4}{*}{ Post funeral - pre funeral } & Negative Ranks & $2 \mathrm{j}$ & 11.00 & 22.00 \\
\hline & Positive Ranks & $42 \mathrm{k}$ & 23.05 & 968.00 \\
\hline & Ties & 171 & & \\
\hline & Total & 61 & & \\
\hline \multirow[t]{4}{*}{ Post hospital - pre hospital } & Negative Ranks & $10 \mathrm{~m}$ & 16.40 & 164.00 \\
\hline & Positive Ranks & $28 n$ & 20.61 & 577.00 \\
\hline & Ties & 230 & & \\
\hline & Total & 61 & & \\
\hline \multirow[t]{4}{*}{ Post govt. - pre govt. } & Negative Ranks & $16 p$ & 16.34 & 261.50 \\
\hline & Positive Ranks & $18 q$ & 18.53 & 333.50 \\
\hline & Ties & $27 r$ & & \\
\hline & Total & 61 & & \\
\hline \multirow[t]{4}{*}{ Post employment - pre employment } & Negative Ranks & $15 \mathrm{~s}$ & 17.17 & 257.50 \\
\hline & Positive Ranks & $17 t$ & 15.91 & 270.50 \\
\hline & Ties & $29 \mathrm{u}$ & & \\
\hline & Total & 61 & & \\
\hline \multirow[t]{4}{*}{ Post sightseeing - pre sightseeing } & Negative Ranks & $27 v$ & 20.76 & 560.50 \\
\hline & Positive Ranks & 10w & 14.25 & 142.50 \\
\hline & Ties & $24 \mathrm{x}$ & & \\
\hline & Total & 61 & & \\
\hline \multirow[t]{4}{*}{ Post workship - pre workship } & Negative Ranks & $17 y$ & 16.44 & 279.50 \\
\hline & Positive Ranks & $13 z$ & 14.27 & 185.50 \\
\hline & Ties & 31 aа & & \\
\hline & Total & 61 & & \\
\hline \multirow[t]{4}{*}{ Post shopping - pre shopping } & Negative Ranks & $20 \mathrm{ab}$ & 15.13 & 302.50 \\
\hline & Positive Ranks & $9 \mathrm{ac}$ & 14.72 & 132.50 \\
\hline & Ties & $32 \mathrm{ad}$ & & \\
\hline & Total & 61 & & \\
\hline \multirow[t]{4}{*}{ Post marriage - pre marriage } & Negative Ranks & $12 \mathrm{ae}$ & 11.50 & 138.00 \\
\hline & Positive Ranks & $13 a f$ & 14.38 & 187.00 \\
\hline & Ties & $36 a g$ & & \\
\hline & Total & 61 & & \\
\hline
\end{tabular}

There is acceptance of the new normal, but only time will tell how things will turn out once this scary phase is over. Humans have a tendency to go back to their old habits, but there is definitely going to be a major change in the future. The author concludes stating that the consumer behaviour will be affected mostly by accepting the regulations at public places because of social distancing, transformation due to the technology and the changing demographics. The discipline of consumer behaviour is now much more dynamic and needs constant monitoring.

\section{Objectives of the Study}

1. To evaluate the change in preference of BEST Bus 
services post lockdown.

2. To find influence of population strata on preference of BEST Bus post lockdown.

\section{Hypotheses of the Study}

1. There is no change in preference of BEST Bus services post lockdown.

2. There is no difference in preference of BEST Bus services and demographic profile.

Table 4. Test Statistics

\begin{tabular}{|l|l|l|}
\hline Particulars & Z value & P value \\
\hline Post workplace-pre workplace & -4.396 & .000 \\
\hline Post native-pre native & -0.957 & .339 \\
\hline Post education-pre education & -5.832 & .000 \\
\hline Post funeral-pre funeral & -5.569 & .000 \\
\hline Post hospital-pre hospital & -3.051 & .002 \\
\hline Post govt.-pre govt. & -0.641 & .521 \\
\hline Post employment-pre employment & $-0,128$ & .898 \\
\hline Post sightseeing-pre sightseeing & -3.219 & .001 \\
\hline Post workship-pre workship & -0.997 & .319 \\
\hline Post shopping-pre shopping & -1.89 & 0.59 \\
\hline Post marriage-pre marriage & -0.703 & .482 \\
\hline
\end{tabular}

\section{RESEARCH METHODOLOGY}

Sources: Primary data is collected through online questionnaire and secondary data is collected from online material.

Sampling method: Non -random convenience sampling.

\section{Sample size: 61}

Sample design: Residents of Mumbai City.

Statistical tools: The data was analysed using SPSS (Statistical Package for Social Science), mean, frequencies, percentages, t-test, wilcoxon signed rank test.

Limitation of the Study: The study is restricted to a small sample size and analyses only the change in preference of Mumbaikar's post lockdown towards BEST BUS for commuting to various destinations.

\section{RESULTS AND DISCUSSION}

Data Collection and Respondent Profile: Data has been collected from total 61 respondents out of which 34 are female respondents and 27 are male respondents.

Table 5. Tests of Normality

Figure 1

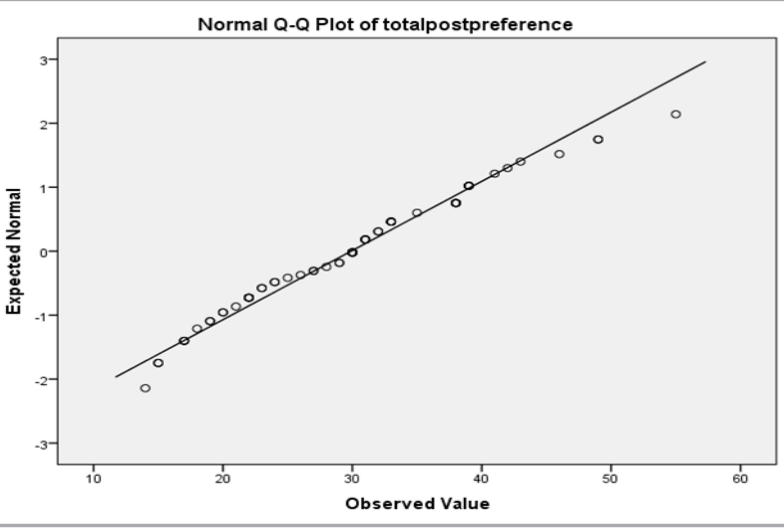

As per Table No.2 out of total 61 respondents; 29 respondents are students, 25 respondents are salaried people, 3 respondents have their own business and 4 respondents are not working.

Difference of post and pre scores was computed for each indicator to access normality in the data set. Kolmogorov-Smirnov P-value was less than .050 in all the cases indicating data not normally distributed. The researcher tried correcting the data problem through square root transformation, log transformation and reciprocal transformation, but fails to solve the problem of converting the data into normal distribution and thus applied non-parametric Wilcoxon Signed Rank Test.

Table 7. Group Statistics

\begin{tabular}{|l|c|c|c|c|c|}
\hline & gender & $\mathrm{N}$ & Mean & Std. Deviation & Std. Error Mean \\
\hline \multirow{2}{*}{ Total preference } & Male & 27 & 41.2963 & 12.67892 & 2.44006 \\
\cline { 2 - 6 } & female & 34 & 30.3235 & 9.66004 & 1.65668 \\
\hline
\end{tabular}




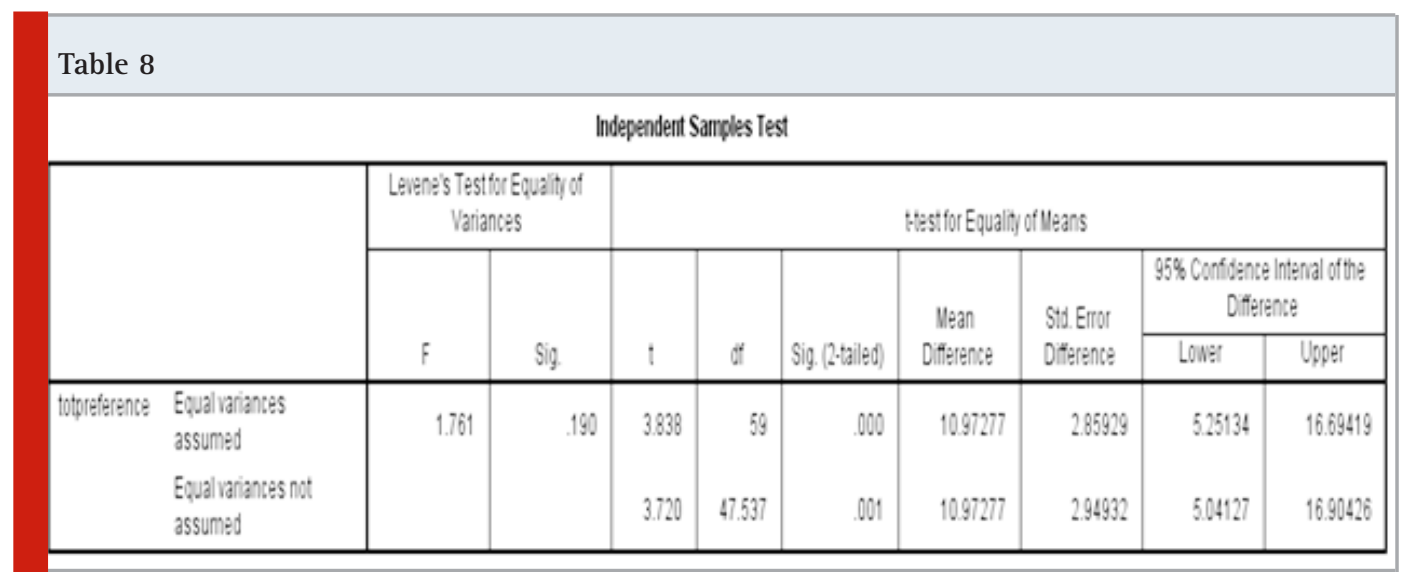

As per table no. 3 and table no.4 it can be clearly seen that there is a significant increase of mean rank in preference of using BEST BUS for workplace, attending funeral $\mathrm{Ct}$ visiting hospital post lockdown as p value is less than the level of significance .05 . Also, it can be seen that there is a significant decrease of mean rank in preference of using BEST BUS for education and sightseeing post lockdown as $\mathrm{p}$ value is less than the level of significance .05.

As per table No.5 Kolmogorov-Smirnov P-value $=.200$ which is greater than .05 which indicates data is normally distributed. Also, as per figure No.6 as all the values are close to the principal diagonal indicating normality in the data set. Since the assumption of parametric test has been fulfilled independence t-test is applied to examine the difference in preference of BEST BUS in male and female respondents.

\section{CONCLUSION}

It is concluded that the preference for the BEST bus post lockdown has increased for going to work, attending funerals and visiting hospitals. This can be mainly because of the easy availability of buses, the absence of local trains and the buses being cost effective in comparison to other available modes. This is a positive aspect for BEST, and in case the people are satisfied, they might opt for the service in the coming days as well. The decrease in preference for services was seen towards educational purpose and sight- seeing. The only reason for this is the shutdown of the educational institutions and the fear of contracting the virus. The demographics revealed an increase in the usage of services by males, which can be attributed to non- availability of local trains for them.

Direction For Future Studies: Further, researches can be conducted to find out the various factors that contribute to the change in commuting preferences post lockdown and the satisfaction level of commuters towards public transport.

\section{REFERENCES}

\section{Books}

Kothari, C.R., Garg, G. (2019). Research Methodology Fourth Edition. New Delhi: New Age International Publications.

Mohan,S., Elangovan,R. (2017). Research Methodology in Commerce. New Delhi: Deep and Deep Publications.

\section{Research Papers}

Gutierrez, A., Miravet, Daniel \&t Domenech, A. (2020, July). COVID-19 and Urban Public Transport Services: Emerging Challenges and Research Agenda, Cities \& Health, DOI:10.1080/23748834.2020.1804291, (Print) (Online) Journal, p. 1-4.

Shen, J., Duan, H., Zhang, B., Wang, J., Ji, J., Wang, J., Pan, L... Shi, X. (2020, July).Prevention And Control of COVID-19 in Public Transportation: Experience from China. Environmental Pollution, 266 115291, p. 1-5DOI: 10.1016/j.envpol.2020.115291

Sheth, Jagdish (2020). Impact of Covid-19 on Consumer Behavior: Will the old habits return or die?. Journal of Business Research 117, p. 280-283.

\section{Online links}

Retrieved January 05, $2021 \mathrm{https} / / /$ www.theweek. in/news/biz-tech/2020/11/09/india-likely-to-seebehavioural-change-in-urban-mobility-post-covidpuri.html

Retrieved January 05, 2021 https://theprint.in/india/8hours-just-to-get-to-from-work-why-despite-openingup-travel-in-mumbai-is-a-nightmare/512182/

Retrieved January 06, 2021 https://www.hindustantimes. com/mumbai-news/public-transport-usage-to-seedecline-after-covid-19-outbreak-ends-study/storyOkwrdWvCfX809fKi6fD6aM.html 